\title{
PENERAPAN PENDEKATAN PRAGMATIK (PRINSIP-PRINSIP PENGGUNAAN BAHASA) DISERTAI TEKNIK KOREKSI SESAMA TEMANDAN KOREKSI OLEH GURU UNTUK MENINGKATKAN KETERAMPILAN MENCERITAKAN PENGALAMAN PADA SISWA KELAS VIIE SMP NEGERI 5 NEGARA
}

\author{
I Putu Mas Dewantara \\ Program Studi Pendidikan Bahasa dan Sastra Indonesia \\ Universitas Pendidikan Ganesha Singaraja
}

\begin{abstract}
This research was intended to (1) describe the development of telling experience skill of the students of class VII E SMP Negeri 5 Negara through the implementation of pragmatic approach (principles of language use) accompanied by pair correction technique and correction by Teacher, (2) describe the steps of learning and teaching activities in the implementation of pragmatic approach (principles of language use) accompanied by pair correction technique and correction by Teacher to develop the skill of telling experiences by the students of VII E SMP Negeri 5 Negara, and (3) describe students' response about the implementation of pragmatic approach (principles of language use) accompanied by pair correction technique and correction by teacher. The subjects of this research were students and teacher of bahasa Indonesia in SMP Negeri 5 Negara. This research used the two-cycle classroom action research. The data about the skill of telling experiences was gathered through test method analyzed by qualitative description method. The data about students' response was gathered through questionnaire method analyzed by qualitative description and quantitative description. The result of the research showed that the implementation of pragmatic approach (principles of language use) accompanied by pair correction technique and correction by teacher can (1) develop the skill of telling experience by students, (2) be done through 19 appropriate learning steps, and (3) develop students' positive response in telling experience. Bahasa Indonesia's teachers is hoped to implement the pragmatic approach (principles of language use) accompanied by pair correction technique and correction by teacher to develop the skill of telling students' experiences that make the teaching-learning activity can run conducive, creative, and innovative.
\end{abstract}

Key words: pragmatic approach, correction technique, the skill of telling experiences

\section{PENDAHULUAN}

Pengembangan ilmu pengetahuan dan teknologi harus ditunjang oleh kemampuan pemanfaatan, pengembangan, dan penguasaan ilmu terapan dan ilmu pengetahuan dasar secara seimbang. Salah satu usaha untuk meningkatkan penguasaan pengetahuan dasar adalah dengan meningkatkan 
keterampilan berbahasa. Dalam lampiran Peraturan Menteri Pendidikan Nasional Republik Indonesia Nomor 22 tahun 2006 tentang Standar Isi untuk Satuan Pendidikan Dasar dan Menengah, khususnya tentang standar kompetensi dan kompetensi dasar mata pelajaran Bahasa Indonesia SMP/MTs secara eksplisit dinyatakan bahwa bahasa memiliki peran sentral dalam perkembangan intelektual, sosial, dan emosional peserta didik, serta merupakan penunjang keberhasilan dalam mempelajari semua bidang studi. Pembelajaran bahasa diharapkan membantu peserta didik mengenal dirinya, budayanya, budaya orang lain, mengemukakan gagasan dan perasaan, berpartisipasi dalam masyarakat yang menggunakan bahasa tersebut. Selain itu, pembelajaran bahasa juga diharapkan membantu peserta didik menemukan serta menggunakan kemampuan analitis dan imaginatif yang ada dalam dirinya.

Standar kompetensi mata pelajaran bahasa Indonesia berorientasi pada hakikat pembelajaran bahasa bahwa belajar bahasa adalah belajar berkomunukasi dan belajar sastra adalah belajar menghargai manusia dan nilainilai kemanusiaannya (Muslim, 2007).
Ruang lingkup mata pelajaran Bahasa Indonesia mencakupi komponen kemampuan berbahasa dan kemampuan bersastra. Kemampuan berbahasa meliputi aspek-aspek:

mendengarkan, (2) berbicara, membaca, dan (4) menulis. Berdasarkan pernyataan tersebut dapat ditegaskan bahwa keterampilan berbicara merupakan salah satu aspek kemampuan berbahasa yang wajib dikembangkan di SMP. Berbicara adalah aktivitas bahasa kedua yang dilakukan manusia dalam kehidupan berbahasa, yaitu setelah aktivitas mendengarkan (Nurgiyantoro, 2001:276).

Mempunyai keterampilan berbicara tidaklah semudah yang dibayangkan. Arsjad dan Mukti U.S. (1993:1) berpendapat bahwa kadangkadang pokok pembicaraan yang disampaikan oleh seseorang cukup menarik, tetapi karena penyajiannya kurang menarik, hasilnyapun kurang memuaskan. Oleh kerena itulah, keterampilan berbicara perlu terus dilatihkan. Walaupun keterampilan berbicara sudah diajarkan sejak dulu, sering kita jumpai seorang siswa yang tidak mampu berbicara dengan baik. Apalagi ketika berbicara di depan kelas. 
Suara yang tersendat-sendat, keringat bercucuran, tegang, dan gugup adalah beberapa ciri siswa yang masih rendah kemampuan berbicaranya.

$$
\text { Kenyataan rendahnya }
$$

keterampilan berbicara yang dimiliki oleh siswa juga terlihat pada siswa kelas VIIE SMPN 5 Negara. Berdasarkan hasil observasi awal dan wawancara dengan guru bidang studi bahasa Indonesia, diketahui bahwa nilai ratarata keterampilan berbicara dari 35 orang siswa adalah 58,86 sedangkan ketuntasan belajar berbicara siswa di SMP ini adalah 67,50. Siswa yang telah dikategorikan tuntas sebanyak 8 orang $(22,86 \%)$, sisanya 27 orang $(77,14 \%)$ belum tuntas. Setelah ditelusuri, kesulitan belajar berbicara siswa kelas VIIE disebabkan oleh dua faktor, yaitu faktor eksternal dan faktor internal. Yang termasuk faktor eksternal, di antaranya pengaruh penggunaan bahasa Indonesia di lingkungan keluarga dan masyarakat. Selain itu, faktor internal yang berpengaruh terhadap rendahnya keterampilan berbicara siswa adalah (1) pendekatan pembelajaran yang masih konvensional, (2) kesulitan dalam mengonstruksi pengetahuan atau pengalaman yang dimiliki, (3) perasaan malu atau grogi, dan (4) adanya gangguan dari siswa lain saat tampil berbicara.

Menyadari hal tersebut, guru telah berusaha mengadakan variasi dalam pembelajaran, seperti dengan melatih siswa bebicara melalui diskusi. Namun, hasil yang didapatkan belum sesuai harapan. Bahkan, tetap saja ada siswa yang masih enggan tampil ke depan kelas ketika diminta berbicara di hadapan teman-temannya. Mungkin salah satu penyebabnya adalah pembentukan anggota kelompok diskusi yang tidak dilakukan oleh guru.

Melihat kenyataan tersebut, perlu adanya suatu penelitian tindakan untuk meningkatkan keterampilan berbicara siswa kelas VIIE SMPN 5 Negara. Upaya tersebut dilakukan dengan memandang bahasa sebagai suatu sistem terbuka. Bahasa tidak bisa dilepaskan dari keberadaan faktor eksternal bahasa, yaitu ciri sosial, ciri biologis, dan sebagainya (Arifin, 2006:46). Pendekatan pembelajaran yang memandang bahasa sebagai suatu yang terpisah dari faktor eksternal bahasa akan menonjolkan pembelajaran mengenai kaidah kebahasaan, seperti dalam pendekatan struktural yang mencurahkan pengajaran bahasa pada lafal kata dan pola-pola kalimat dengan 
cara latihan berkali-kali (Nababan dalam Arifin, 2006:46). Pendekatan struktural pernah diterapkan di sekolahsekolah, yaitu pada kurikulum 1975 yang kemudian dianggap gagal dalam pembelajaran bahasa karena hanya memberikan pengetahuan tentang bahasa kepada siswa. Jika kita tinjau KTSP mengenai pengajaran bahasa Indonesia, siswa dituntut untuk mampu menggunakan bahasa secara praktis, bukan sesuatu yang teoretis mengenai bahasa.

Pendekatan pembelajaran yang disinyalir mampu memberikan pengetahuan mengenai penggunaan bahasa senyatanya adalah pendekatan pragmatik dengan memberikan pengetahuan mengenai prinsip-prinsip pemakaian bahasa. Prinsip-prinsip pemakaian bahasa yang diterapkan dalam pendekatan pragmatik, yaitu (1) penggunaan bahasa dengan memperhatikan prinsip-prinsip kerja sama, (2) penggunaan bahasa dengan memperhatikan prinsip-prinsip kesantunan, (3) penggunaan bahasa dengan memperhatikan aneka aspek situasi ujaran, dan (4) penggunaan bahasa dengan memperhatikan faktorfaktor penentu tindak komunikatif (Asrory, 2004).
Peningkatan keterampilan berbicara siswa Kelas VIIE SMPN 5 Negara dengan pemberian pengetahuan mengenai prinsip-prinsip penggunaan bahasa disertai teknik koreksi sesama teman dan koreksi oleh guru pada dasarnya bertujuan untuk melatih siswa menggunakan bahasa dengan mengaitkan bahasa dengan unsur-unsur di luar bahasa dan memperbaiki kesalahan-kesalahan siswa dalam berbicara. Baik itu kesalahan ucapan, diksi, kekeliruan pemberian tekanan, gerak-gerik dan mimik yang tidak tepat, kesalahan pemilihan bahasa yang berhubungan dengan prinsip-prinsip kerjasama dan prinsip kesantunan serta hal-hal lain saat siswa bertindak tutur.

Teknik koreksi oleh sesama teman dan oleh guru ini dipilih selain bertujuan untuk memperbaiki kesalahan siswa yang melakukan tindak tutur juga untuk menciptakan suasana kelas yang kondusif. Sumarsono menyatakan bahwa hambatan-hambatan yang dihadapi oleh seorang siswa dalam pembelajaran berbicara adalah: (1) gangguan psikis, seperti gagap, gugup, malu, demam panggung, kelelahan, (2) gangguan fisik, seperti tidak mampu melafalkan /r/ dengan baik, (3) guru terlalu banyak mencela ketika siswa 
tampil berbicara, (4) guru terlalu ketat menuntut dipakainya ragam baku, dan (5) pengaruh lingkungan, seperti gangguan teman sekelas atau karena bising. Dengan teknik koreksi oleh sesama teman, hambatan nomor lima setidaknya dapat diatasi.

Keterlibatan guru dalam memberikan masukan-masukan kepada siswa tentunya akan semakin memperdalam pemahaman siswa terhadap kesalahan yang dilakukan. Mungkin saja nantinya ada kesalahan atau kekurangan-kekurangan lain yang belum disampaikan oleh siswa ketika mengomentari temannya, saat itulah guru akan menambahkannya. Sepengetahuan penulis, penelitian dengan penggunaan pendekatan pragmatik yaitu prinsip-prinsip penggunaan bahasa disertai teknik koreksi sesama teman dan koreksi oleh guru untuk meningkatkan keterampilan menceritakan pengalaman belum pernah dilakukan. Penelitian-penelitian sejenis yang bertujuan untuk meningkatkan keterampilan berbicara siswa dengan rekomendasi yang dapat dijadikan bahan pertimbangkan untuk menyusun langkah pembeajaran dalam penelitian ini adalah penelitian yang berjudul Efektivitas Masyarakat-Belajar
(Learning Community) dalam Wujud Diskusi Kelompok Kecil untuk Meningkatkat Keterampilan Berbicara Siswa Kelas VIIIA SMP Negeri 2 Penebel oleh Ni Made Rai Wisudariani tahun 2008. Menurut Rai, pembentukan kelompok yang bersifat heterogen dalam hal akademis, gender, dan latar belakang sosial ekonomi menjadikan suasana pembelajaran semakin kondusif. Penelitian lain yang rekomendasinya dapat dijadikan bahan pertimbangan adalah penelitian yang berjudul Penerapan Model Pembelajaran Konstruktivisme dengan Media Wayang untuk Meningkatkan Keterampilan Berbicara Siswa Kelas VIIB SMP Negeri 2 Ubud oleh Ade Suryadana tahun 2009. Ade merekomendasikan agar dalam pembelajaran berbicara, siswa diberikan kesempatan untuk mengkonstruksi pemahamannya sendiri.

Adapun perasalahan yang diangkat dalam penelitian ini, yaitu: (1) Bagaimanakah peningkatan keterampilan menceritakan pengalaman siswa kelas VIIE SMPN 5 Negara dengan penerapan pendekatan pragmatik (prinsip-prinsip penggunaan bahasa) yang disertai teknik koreksi sesama teman dan koreksi oleh guru? ; 
(2) Bagaimanakah langkah-langkah pembelajaran yang ditempuh?; (3) Bagaimanakah respons siswa terhadap pembelajaran yang menggunakan penerapan pendekatan pragmatik (prinsip-prinsip penggunaan bahasa) yang disertai teknik koreksi sesama teman dan koreksi oleh guru? Hasil penelitian ini dapat berguna untuk siswa, guru Bahasa Indonesia, mahasiswa Bahasa dan Sastra Indonesia, dan peneliti lain.

\section{METODE PENELITIAN}

Penelitian ini menggunakan rancangan penelitian tindakan kelas (PTK). Dari namanya sudah menunjukkan isi yang terkandung di dalamnya, yaitu sebuah kegiatan penelitian yang dilakukan di dalam kelas (Arikunto, dkk, 2008:2). Penelitian ini dilaksanakan dalam dua siklus. Subjek penelitian adalah benda, hal atau orang tempat variabel melekat, dan yang dipermasalahkan dalam penelitian. Subjek penelitian ini adalah guru dan siswa SMPN 5 Negara (Wendra, 2009:32). Objek penelitian ini adalah keterampilan menceritakan pengalaman, langkah-langkah pembelajaran, dan respons siswa.
Metode yang dipergunakan untuk mengumpulkan data-data yang diperlukan, yaitu metode tes untuk mengumpulkan data mengenai keterampilan menceritakan pengalaman siswa. Metode observasi dipergunakan untuk memperoleh data mengenai langkah-langkah pembelajaran. Metode angket/kuesioner untuk memperoleh data mengenai respons siswa.

Secara individual siswa dikatakan tuntas dalam pembelajaran menceritakan pengalaman apabila nilai yang diperoleh minimal 67,50. Hal ini didasarkan atas kreteria ketuntasan minimal di SMPN 5 Negara. Secara klasikal, pembelajaran dikatakan tuntas jika $75 \%$ dari jumlah siswa yang ada di kelas itu memperoleh nilai minimal 67,50, sehingga tindakan dapat dihentikan.

\section{HASIL DAN PEMBAHASAN \\ Penerapan Pendekatan Pragmatik (Prinsip-Prinsip Penggunaan Bahasa) Disertai Teknik Koreksi Sesama Teman dan Koreksi oleh Guru}

Penerapan pendekatan pragmatik (prinsip-prinsip penggunaan bahasa) disertai teknik koreksi sesama teman dan koreksi oleh guru dapat meningkatkan keterampilan menceritakan pengalaman siswa kelas 
VIIE SMPN 5 Negara. Hal ini dapat dilihat dari nilai keterampilan menceritakan pengalaman siswa sebelum diberikan perlakuan dengan nilai rata-rata 58,86. Setelah diberikan perlakuan pada siklus I, nilai rata-rata siswa adalah 70,11. Ini berarti terjadi peningkatan nilai rata-rata dari sebelum diberikan perlakuan sampai siklus I sebesar 11,87 .

Berdasarkan hasil siklus I, ditemukan bahwa (1) banyak siswa terlihat telah mampu menggunakan kalimat efektif dan runtut. Namun, volume suara mereka masih terlalu kecil, (2) masih banyak siswa yang belum mampu merumuskan tujuan penceritaan pengalamannya dengan baik, dan (3) mimik dan gestur siswa dalam bercerita masih sangat kurang. Mereka cenderung hanya diam ketika bercerita. Hanya gerakan berupa gerakan tangan yang sangat minim yang tampak.

Kelemahan pada siklus I diatasi dengan pemberian pemahaman mengenai faktor-faktor penunjang keefektipan berbicara kepada siswa. Pemahaman mengenai faktor-faktor penunjang keefektipan berbicara dapat memotivasi siswa untuk menyampaikan ceritanya dengan lebih baik. Masalah seperti volume suara, diksi, pemberian tekanan, dan masalah-masalah nonkebahasaan seperti gestur juga mampu diatasi.

Pada siklus II, skor rata-rata siswa adalah 73,93 . Jumlah peningkatan nilai rata-rata dari siklus I ke siklus II adalah 3,82 . Hasil pada tindakan kedua, dapat dikatakan sebagai tindakan terbaik, karena mampu meningkatkan hasil pembelajaran menceritakan pengalaman siswa. Dari 35 orang siswa kelas VIIE ada sebanyak tiga puluh satu orang atau $88,57 \%$ memeroleh nilai $\geq 67,50$. Hasil tersebut telah memenuhi kriteria yang sudah ditetapkan peneliti yaitu $75 \%$ siswa di kelas memperoleh nilai 67,50 ke atas. Di samping itu, temuan yang paling berarti dalam penerapan pendekatan pragmatik (prinsip-prinsip penggunaan bahasa) disertai teknik koreksi sesama teman dan koreksi oleh guru adalah dapat menciptakan suasana belajar yang kondusif, kreatif, dan inovatif.

\section{Langkah-langkah Pembelajaran}

Langkah-langkah pembelajaran yang tepat dalam penerapan pendekatan pragmatik (prinsip-prinsip penggunaan bahasa) disertai teknik koreksi sesama teman dan koreksi oleh guru dapat 
meningkatkan keterampilan

menceritakan pengalaman siswa kelas VIIE SMPN 5 Negara adalah (1) Guru menyampaikan apersepsi, (2) Guru menceritakan sebuah pengalaman, (3) Guru menyampaikan tujuan pembelajaran, (4) Guru dan siswa berdiskusi mengenai cerita yang disampaikan oleh guru, (5) Guru menugasi siswa untuk mendata pengalaman mengesankan yang dimiliki kemudian memilih salah satu dari pengalaman tersebut, (6) Siswa menentukan partisipan yang terlibat dalam pengalaman yang akan diceritakan, (7) Siswa menentukan tujuan penyampaian pengalaman yang diceritakan, (8) Siswa merangkai cerita berdasarkan data-data yang telah dibuat, (9) Guru dan siswa berdiskusi mengenai faktor-faktor penunjang keefektipan berkomunikasi, (10) Siswa menceritakan pengalaman yang telah dibuat, (11) Siswa dan guru memberikan koreksi terhadap tampilan siswa, (12) Guru memberikan kesempatan kepada siswa untuk bertanya, (13) Guru membagi siswa dalam 3 kelompok, (14) Guru menugaskan siswa untuk bercerita dalam kelompoknya, (15) Siswa memberikan koreksi terhadap penceritaan temannya, (16) Guru memberikan koreksi terhadap penampilan siswa, (17) Guru bersama siswa mengadakan refleksi, (18) Guru memberikan kesempatan kepada siswa untuk bertanya, dan (19) Guru bersama siswa menyimpulkan dan menutup pembelajaran.

Temuan-temuan penting berdasarkan pada penelitian ini adalah, pertama, penerapan pendekatan pragmatik (prinsip-prinsip penggunaan bahasa) berpeluang membuat siswa belajar bahasa, khususnya berbicara tidak hanya sekadar belajar mengenai teori-teori berbicara yang baik namun juga belajar menggunakan bahasa dalam situasi yang kompleks. Hal ini senada dengan yang diungkapkan oleh Purwo (dalam Sumardi, Ed, 1992) yang mengibaratkan belajar berbahasa dengan pendekatan pragmatik sebagai kemampuan berenang. Belajar bahasa bukanlah mempelajari cara atau petunjuk yang berkaitan dengan renang, melainkan terjun dan berkecimpung dengan air, mengalami gelagapan, mengalami hidung kemasukan air, dan sebagainya yang timbul selama berada di dalam air. Pelajaran bahasa tidak dapat disamakan dengan pelajaran menghafalkan rumus-rumus kimia atau 
menghafalkan tahun-tahun pada peristiwa sejarah. Pelajaran bahasa lebih mirib dengan pelajaran menyanyi atau pelajaran merangkai bunga, yakni berisi kegiatan berbuat sesuatu, melakukan tindakan sesuatu. Pengibaratan yang diberikan Purwo ini nampaknya sejalan dengan Dell Hymes (dalam Sumarsono, 2007:5) yang menyatakan bahwa untuk mampu berbahasa (bertutur) atau berkomunikasi dalam bahasa orang tidak cukup hanya menguasai kaidah gramatika saja, melainkan juga harus mengetahui cara penggunaannya dalam komunikasi.

Kedua, penerapan teknik koreksi sesama teman dan koreksi oleh guru juga akan membantu siswa meningkatkan keterampilan berbicara siswa. Hambatan gangguan dari teman setidaknya dapat diatasi dengan penggunaan teknik ini. Penggunaan teknik koreksi sesama teman akan semakin efektif jika diterapkan dengan cara menunjuk siswa yang memberikan koreksi sehingga siswa lebih memperhatikan temannya ketika tampil menceritakan pengalaman mengesankan. Hal ini seperti yang diterapkan dalam siklus II dan berhasil menciptakan kondisi lebih kondusif.
Ketiga, motivasi mendorong siswa ingin melakukan kegiatan belajar. Para ahli psikologi mendefinisikan motivasi sebagai proses di dalam diri individu yang aktif, mendorong, memberikan arah, dan menjaga perilaku setiap saat (Slavin, tt). Pemberian motivasi dalam proses pembelajaran ternyata dapat menumbuhkan rasa percaya dalam diri siswa untuk tampil dengan lebih baik.

\section{Keempat, pengkonstruksian} pengetahuan oleh diri siswa sendiri membuat siswa lebih memahami materi pembelajaran. Siswa menemukan sendiri bagaimana cara menyampaikan cerita berdasarkan pendekatan pragmatik (prinsip-prinsip penggunaan bahasa) dan tahu hal-hal apa yang perlu mendapat perhatian dalam bercerita setelah mereka menemukan sendiri faktor-faktor penunjang keefektipan berbicara. Di samping itu, pemodelan penceritaan pengalaman mengesankan juga membawa dampak siswa lebih berani dalam memberikan koreksi terhadap penampilan temannya. Siswa memberikan koreksi berdasarkan faktor-faktor penunjang keefektifan berbicara yang baru mereka temukan.

Kelima, pembagian kelompok dengan jumlah anggota kelompok yang 
tidak terlalu besar yang setiap kelompok didampingi oleh seorang observer menjadikan suasana kelas lebih kondusif. Siswa menjadi fokus menyimak penyampaian cerita yang disampaikan oleh teman mereka sehingga mereka tidak memiliki kesempatan untuk mengganggu temannya yang sedang bercerita.

Keenam, penekanan pemahaman mengenai pentingnya keterampilan berbicara dan teknik belajar menceritakan pengalaman mengakibatkan siswa lebih percaya diri dan bersemangat dalam belajar. Hal ini seperti yang diungkapkan oleh De Porter (dalam Ade Suryadana, 2009:134) bahwa pengetahuan akan manfaat sesuatu sama dengan menciptakan minat terhadap sesuatu.

\section{Respons Siswa terhadap}

\section{Pembelajaran}

Penerapan pendekatan pragmatik (prinsip-prinsip penggunaan bahasa) disertai teknik koreksi sesama teman dan koreksi oleh guru dapat menumbuhkan respons positif siswa terhadap pembelajaran menceritakan pengalaman siswa kelas VIIE SMPN 5 Negara. Hal ini dapat dilihat dari jawaban kuesioner siswa yang menunjukkan sikap positif dan sangat positif. Untuk respons siswa persentase peningkatan rata-rata dari siklus I ke siklus II mengalami peningkatan sebesar 1,71. Jumlah rata-rata skor respons siswa pada siklus I 25,89 menjadi 27,60 pada siklus II. Pada siklus I, ada 20 orang $(57,14 \%)$ yang memberikan respons sangat positif, 14 orang $(40 \%)$ yang memberikan respons positif dan 1 orang $(2,86 \%)$ yang memberikan respons cukup positif. Pada Siklus II, dari 35 orang yang mengisi angket, ada 30 orang $(85,71 \%)$ yang memberikan respons sangat positif dan 5 orang $(14,29 \%)$ yang memberikan respons positif. Jadi, respons siswa dapat dikatakan tuntas karena sudah melebihi kriteria ketuntasan yang telah ditentukan, yaitu $75 \%$ siswa memberikan respons positif.

\section{PENUTUP}

Hasil penelitian ini menunjukkan bahwa penerapan pendekatan pragmatik (prinsip-prinsip penggunaan bahasa) disertai teknik koreksi sesama teman dan koreksi oleh guru dapat: (1) meningkatkan keterampilan menceritakan pengalaman siswa kelas VIIE SMPN 5 Negara. Hal ini dapat dilihat dari nilai keterampilan menceritakan pengalaman siswa 
sebelum diberikan perlakuan dengan nilai rata-rata 58,86 . Setelah diberikan perlakuan pada siklus I, nilai rata-rata siswa adalah 70,11. Pada siklus II, skor rata-rata siswa adalah 73,93 . Jumlah peningkatan nilai rata-rata dari siklus I ke siklus II adalah 3,82. Dari 35 orang siswa kelas VIIE ada sebanyak tiga puluh satu orang atau $88,57 \%$ memeroleh nilai $\geq 67,50$. Hasil tersebut telah memenuhi kriteria yang sudah ditetapkan peneliti yaitu $75 \%$ siswa di kelas memperoleh nilai 67,50 ke atas; (2) dilakukan dengan langkah-langkah pembelajaran yang tepat, yaitu sebanyak 19 langkah pembelajaran; dan (3) siswa memberikan respons positif terhadap kegiatan pembelajaran.

Hasil penelitian ini bermanfaat bagi guru dan siswa dalam pembelajaran berbicara, khusus pembelajaran menceritakan pengalaman. Oleh karena itu, khususnya peneliti menyarankan supaya guru mata pelajaran Bahasa dan Sastra Indonesia hendaknya menerapkan pendekatan pragmatik (prinsip-prinsip penggunaan bahasa) disertai teknik koreksi sesama teman dan koreksi oleh guru untuk meningkatkan kemampuan berbicara siswa secara lebih mendalam, agar siswa juga memiliki pemahaman yang baik mengenai pembelajaran tersebut, sehingga pembelajaran pun berlangsung dalam kondisi lingkungan yang kondusif.

\section{DAFTAR PUSTAKA}

Arifin. (2006). Penerapan pendekatan komunikatif dalam pengajaran gramatika di SLTP negeri 1 kota malang. Prasi (Jurnal Bahasa, Seni, dan Pengajaran) Vol.4 No. 7 Januari-Juni 2006.

Arikunto, dkk. (2008). Penelitian tindakan kelas. Jakarta: PT Bumi Aksara.

Arsjad, Maidar G. dan Mukti U.S .(1993). Pembinaan kemampuan berbicara bahasa indonesia. Jakarta: Erlangga.

Asrory, Zainal. (2004). http://images.zainalasrory.multipl y.com/attachment/0/SEGAygoKC qwAAEvtM5g1/ptk\%20asli\%20b anget.doc?nmid=98785639. Diakses 15 Februari 2008.

Muslim, M. Umar. (2007). KTSP dan pembelajaran bahasa indonesia. http//www.KTSP/KTSP\%20dan \%20Pembelajaran\%20Bahasa\%2 OIndonesia\%20\%C2\%AB\%20\% 7 Bjohnherf\%7D.htm. Diakses 20 Januari 2009.

Nurgiyantoro, Burhan. (2001). Penilaian dalam pengajaran bahasa dan sastra. Yogyakarta: PT BPFE-Yogyakarta.

Sumarsono. (2007). Pragmatik (Buku Ajar). Singaraja: Undiksha. 
Suryadana, Ade. (2009). Penerapan model pembelajaran konstruktivisme dengan media wayang untuk meningkatkan keterampilan berbicara siswa kelas VIIB SMP Negeri 2 Ubud. Skripsi (tidak diterbitkan). Jurusan Pendidikan Bahasa, Sastra Indonesia dan Daerah, FBS Undiksha.

Wendra, I Wayan. (2009). Penulisan karya ilmiah (Buku Ajar). Singaraja: Undiksha. 